\title{
THEREZINHA LINS DE ALBUQUERQUE
}

Homenageada

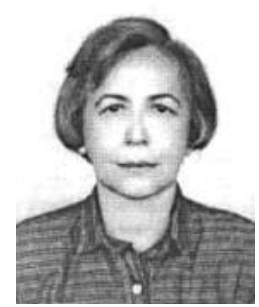

A área da Psicologia Escolar e Educacional tem muito a agradecer a recifense Therezinha Lins de Albuquerque. Formada em pedagogia, dedicou-se à psicologia durante sua trajetória profissional em prol da transformação da educação.

Ao acompanhar o histórico sobre a trajetória de Therezinha Lins pode-se perceber a consistência, a integridade e a coerência, marcadas pela inteligência e sensibilidade. $O$ engajamento frente aos problemas humanos e sociais marcaram a história dessa militante defensora da educação no Brasil. No Rio Grande do Sul, mais especificamente, em Porto Alegre, sua contribuição foi fundamental no desenvolvimento e na capacitação de profissionais educadores e psicólogos nas áreas da Psicologia Escolar, Supervisão e Adolescência, o que aconteceu de 1983 a 1986, nos cursos de especialização do então Instituto de Psicologia da PUCRS do qual Therezinha era diretora. Sua presença e participação também foram decisivas na realização dos sucessivos Encontros de Psicólogos Escolares do Rio Grande do Sul - EPERGS (1982, 1983, 1984, 1985 e 1986), onde a mesma se tornou uma verdadeira referência.

Pelo conhecimento de sua história, percebe-se, nesta contribuição ao Rio Grande do Sul, uma extensão e síntese do que Therezinha havia desenvolvido em anos anteriores. Criou o Serviço de Orientação Psicológica da Escola da Guatemala em 1955. Atuou por 12 anos como Psicóloga, construindo um trabalho de Orientação aos Professores, a convite do Dr. Anísio Teixeira. E a experiência da psicóloga nos anos seguintes mostra o quanto ela acrescentou à Psicologia brasileira: em 1968 foi diretora e supervisora de Psicólogos na Clínica de Adolescentes do Ministério da Saúde do Centro de Orientação Juvenil da Guanabara - COJ; em 1982 criou e coordenou a Comissão de Supervisão do CFP; No ano de 1984 implantou esta Comissão no CRP 07 cuja abordagem se realizou por meio de uma pesquisa sobre a situação da Supervisão na região Sul. No ano seguinte, como resultado deste trabalho, foi criado o Curso de Especialização em Supervisão na PUCRS.

No momento atual, Therezinha Lins volta a ter uma marcante atuação junto aos psicólogos professores de Porto Alegre que estão sendo demitidos da Universidade, solidarizandose com os mesmos e sugerindo a criação de um grupo de reflexão com o objetivo de re-significar a experiência. 